УДК 373.013

DOI:

Ірина Іванюк, кандидат педагогічних наук, стариий науковий співробітник Центру психічного здоров'я та психосочіального супроводу Національного університету “Києво-Могилянська академія”, Інституту інформаційних технологій $i$ засобів навчання Національної академії педагогічних наук України

Вікторія Соловйова, психолог вищьї категорії, психотерапевт, керівник Центру психосочіальної реабілітаиї Національного університету "Києво-Могилянська академія" м. Покровськ

\title{
СТВОРЕННЯ БЕЗПЕЧНОГО ШКІЛЬНОГО СЕРЕДОВИЩА: ПРОТОКОЛ БЕЗПЕКИ ПРИ СУӤЦИДАЛЬНІЙ ПОВЕДІНЦІ ПІДЛІТКІВ
}

У статті розглянуто нормативно-правові документи, щзо передбачають проведення превентивних заходів щодо суїиидальної поведінки підлітків. Надано характеристику рівнів ризику скоєння суїииду. Представлено алгоритм дій педагогічного співробітника за наявності ознак суїиидальної поведінки у підлітків. Запропоновано протокол безпеки супроводу підлітка, який має середній, високий та надвисокий рівень ризику скоєння суїииду. Зазначено, що ефективніть протоколу безпеки доведена на практиці в Центрі психосочіальної реабілітації Національного Університету "Києво-Могилянська Академія".

Ключові слова: суїиидальна поведінка; підліток; протокол безпеки; безпечне шкільне середовище.

Табл. 1. Літ. 10.

Iryna Ivaniuk, Ph.D.(Pedagogy), Senior Researcherof the Mental Health Center of the National University "Kyiv-Mohyla Academy", the Institute of Informational Technologies and Learning Tools of National Academy of Pedagogical Science of Ukraine

Victoria Solovyova, Psychologist of High Category, Psychotherapist, Head of the Center for Psychosocial Rehabilitation of the National University “Kyiv-Mohyla Academy” Pokrovsk

\section{CREATINGA SAFE SCHOOL ENVIRONMENT: PROTOCOL OF SAFETY IN TEENAGERS' SUICIDAL BEHAVIOR}

The article considers the normative and legal documents on the social behavior of children and adolescents. It is determined that using the above-mentioned documents, pedagogical staff of schools have the opportunity to focus on a system of preventive measures. However, the question of the teacher's actions in the presence of signs of suicidal behavior in adolescents remains relevant. It is emphasized that a special role in preventing suicides among adolescents belongs to teachers, because they are the ones who can most often identify those children who have suicidal behavior and provide social and pedagogical assistance, refer to psychological assistance. The issue of developing an algorithm for adult actions in the presence of signs of suicidal behavior and different levels of risk of suicide in adolescents is determined. Four levels of risk of suicide (low, medium, high and ultra-high) are described. An algorithm of the teacher's actions for saving the life of a teenager during a certain level of risk is presented, which provides for verbal consent, written consent, safety plan, referral to a specialist. A safety protocol for the support of a teenager with a medium, high and extremely high risk of suicide has been proposed. The scientific novelty of the study is that for the first time in Ukraine a protocol for accompanying a teenager who has suicidal behavior has been provided for teachers. With a detailed description of the steps, educators will be able to determine the level of risk of possible suicide, provide assistance and support to adolescents who show signs of suicidal behavior. It is noted that the effectiveness of the safety protocol has been proven in practice at the Center for Psychosocial Rehabilitation of the National University "Kyiv-Mohyla Academy".

Keywords: suicidal behavior; teenager; security protocol; safe school environment.

П остановка проблеми. За даними Всесвітньої організації охорони здоров'я, щороку через самогубство помирають 703000 людей, і набагато більше людей намагаються здійснити самогубство. Самогубство було четвертою причиною смертності серед 15-29-річних у всьому світі у 2019 р. 77 \% самогубств у світі відбувається в країнах з низьким та середнім рівнем доходу [1].

В Україні простежується тривожна тенденція до збільшення числа підліткових самогубств. Згідно з даними Єдиного реєстру досудових 
СТВОРЕННЯ БЕЗПЕЧНОГО ШКІЛЬНОГОСЕРЕДОВИЩА: ПРОТОКОЛ БЕЗПЕКИ ПРИ СУӤЩИДАЛЬНІЙ ПОВЕДІНЩ ПДЛІТКІВ

розслідувань України, у 2020 р. 123 підлітки вчинили самогубство, протягом перших трьох місяців 2021 р. відбувся 101 суїцид [2].

Нормативно-правова база країни щодо превенції суїцидальних тенденцій включає низку документів, зокрема, Закон України [3] передбачає кримінальну відповідальність за сприяння вчиненню самогубства. У листі Міністерства освіти і науки України (МОН) “Щодо профілактики суїцидальних тенденцій серед підлітків” [4] виділено певну систему проведення профілактичних заходів, що включають сім компонентів: психологічну просвіту; створення позитивного клімату; діагностику суїцидальних намірів; консультування дітей та сімей; корекцію відхилень; систематичний контроль і динаміка змін у поведінці учнів; напрями переадресування “важких” випадків. У листі МОН “Щодо запобігання та протидії насильству” [5] суїцидальна поведінка підлітків визначається як наслідок жорсткого поводження та насилля й запропоновані напрями роботи 3 дітьми і форми організації діяльності щодо виявлення підлітків, схильних до суїциду.

Використовуючи вищезазначені документи, педагогічні працівники закладів загальної середньої освіти мають можливість орієнтуватися на систему проведення профілактичних заходів. Проте залишається актуальним питання алгоритму дій дорослого за наявності ознак суїцидальної поведінки і різного рівня ризику щодо скоєння самогубства у підлітків.

Аналіз основних досліджень і публікацій. Питання особистісної тривожності розглянуто у роботах А. Прихожана, Ч. Спілберга, Ю. Ханіна та ін.; аналіз суїцидальної поведінки підлітків представлено у роботах О. Боголюбова, М. Гуліна, Н. Сабат та ін.; причини та соціальні фактори суїцидальної поведінки підлітків проаналізовано в дослідженнях Л.Димитрової, Г. Кіхтан, Л. Шевчук, Л. Федоришиної та ін.; особливості психологічної допомоги підліткам з суїцидальною поведінкою розкрито у працях С. Змановської, Л. Шнейдер та ін.; питання щодо профілактики та корекції суїцидальної поведінки у шкільному середовищі висвітлено у роботах О. Бойчук, О. Гука, І. Гриника та ін. Однак проблема практичного психосоціального супроводу підлітків із суӥцидальною поведінкою в шкільному середовищі залишається недостатньо дослідженою.

Мета статті - представити протокол безпеки, що включає в себе супровід підлітка, який має суїцидальну поведінку, щоб педагогічні працівники змогли визначити рівень ризику щодо можливого скоєння суїциду і надати відповідну допомогу та підтримку підлітку.

Основний матеріал дослідження. Особлива роль у запобіганні випадкам суїциду серед підлітків належить/ педагогам, бо саме вони найчастіше можуть виявити тих дітей, які мають суїцидальну поведінку та надати соціальнопедагогічну допомогу, перенаправити на психологічну допомогу [6; 7].

Суїцидальна поведінка - це думки про самогубство, бажання і наміри вбити себе, суїцидальні мотиви, відповідні емоційні переживання (туга, безнадія, тривога, почуття провини), а також конкретні вчинки, спрямовані на заподіяння собі смерті $[8,18]$.

Соціально-педагогічна та психологічна допомога і підтримка передбачає подолання нереалізованості, спустошеності, безпорадності, формування нової життєвої стратегії та рівня світосприймання, набуття навичок конструктивного подолання проблем та виходу із кризових станів $[9,84]$.

Для визначення ризику суїцидальної поведінки серед підлітків педагогічні працівники мають знати поведінкові та комунікативні індикатори суїцидального ризику. Поведінковими індикаторами є: самоізоляція, обмеження контактів з оточенням; зневажливе ставлення до своєї зовнішності та недотримання правил особистої гігієни; втечі 3 дому; теми смерті та самогубств починають домінувати у творчості; прослуховування тематичної музики, що стосується питань смерті, втрати сенсу життя; підвищена тривожність, перепади настрою; здійснення різного роду ритуалів прощання (складання заповіту, роздавання власних речей); відсутність проявів емоційності; самоушкодження. Комунікативними індикаторами $є$ : прямі або непрямі висловлювання дитини про суїцидальні наміри; повідомлення про конкретний план суїциду; низька самооцінка; амбівалентна оцінка важливих подій; сповільненість мови, заповнення мовних пауз глибокими вдихами, монотонність інтонації; ознаки агресії, спрямованої на себе, систематичне самозвинувачення; відсутність планів на майбутнє; запевнення у безпорадності та залежності від інших.

За наявності хоча б одного індикатора в поведінці й розмові підлітка, виникає необхідність перевірити його на рівень ризикованої суїцидальної поведінки.

У рекомендаціях Всесвітньої організації охорони здоров'я запропоновано приблизну шкалу оцінки суїцидального ризику, що налічує чотири рівні [10]. Розглянемо, як здійснюється визначення рівня ризику скоєння суїциду: 
- ризик низький: наявність думок (неоформлені думки, наприклад, “життя складне”, “краще так не жити");

- ризик середній: наявність думок і плану (оформлені думки, наприклад, “всім буде краще без мене", “я вже не витримую”, “я більше не хочу жити"; наявність плану, наприклад, наковтатися пігулок, стрибнути з вікна);

- ризик високий: наявність думок, плану та засобів (оформлені думки; визначений план; наявність засобу, за допомогою якого підліток готовий піти з життя, наприклад, придбав пігулки);

- ризик надвисокий: наявність думок, плану та засобів, є досвід спроб самогубства у минулому.

Залежно від визначеного рівня ризику скоєння суїциду з підлітком психологу або педагогу пропонується спиратися на такий алгоритм дій для збереження життя підлітка та поліпшення його психоемоційного стану:

- низький рівень ризику та неоформлені думки - укладіть 3 підлітком усну угоду, наприклад: “Я, (ім'я), погоджуюся зберегти своє життя, не завдавати собі і своєму здоров'ю шкоду. Даю на це усну згоду";

- середній рівень ризику та оформлені думки, але відсутній план дій - укладіть із підлітком письмову угоду на папері, наприклад: “Я, (ім’я), даю згоду, що буду зберігати своє життя у безпеці, не буду наносити шкоду собі та своєму здоров'ю. Даю на це письмову згоду. Дата, підпис";

- середній рівень ризику з наявним планом дій, високий та надвисокий рівні ризику - необхідно скласти план безпеки, наприклад: “Я, (ім’я), коли у мене з'являться такі думки, як (описати думки),

коли у мене виникнуть загрозливі ознаки, як (описати три ознаки), для того, щоб відволіктися від цих думок, я буду робити (описати три діï). Я спілкуватимуся 3 людьми, які зможуть мене відволікти від думок про самогубство (зазначити імена людей). Я сховаю всі небезпечні предмети (зазначити предмети) з усіх доступних місць i віддам їх (зазначити кому саме). Якщо я відчую, що не зможу це виконати, я зателефоную за номером (-ами) (зазначити номери та імена власників). Я зателефоную на гарячу лінію: 116 111 (безкоштовно з мобільних телефонів) або 0(800)500-225, 7333. Якщо я відчую, що не зможу впоратися зі своїм станом, то запрошу для підтримки (зазначити кого саме). План безпеки діє 3 (дата) по (дата). Дата, підпис".

Для збереження життя та здоров'я дитини, пропонується покроковий протокол безпеки супроводу підлітка, що може здійснювати педагог або практичний психолог, проводячи бесіду 3 дитиною, яка має ознаки суїцидальної поведінки (Табл. 1). Протокол розроблено та успішно використовується на практиці фахівцями Центру психічного здоров'я та психосоціальної реабілатації НаУКМА на основі рекомендацій наукових дослідників Регіонального Центру профілактики насильства, травми та суїцидів, Університетської клініки Акерсхус (м. Осло, Норвегія).

Додаткові дї̈ під час перепідписання плану безпеки з підлітком. Якщо після визначеного терміну у підписаному плані безпеки, наприклад, після трьох днів, рівень суїцидальної поведінки залишається незмінним, - перенаправте дитину до відповідної спеціалізованої установи або до

Таблиця 1.

Протокол безпеки супроводу підлітка, який мас середній, високий та надвисокий ризик скосння суїциду (20 кроків збереження безпеки)

\begin{tabular}{|c|c|c|}
\hline № & Опис дії педагога або психолога & $\begin{array}{c}\text { Приклад того, як слід говорити } 3 \\
\text { дитиною }\end{array}$ \\
\hline Крок 1. & $\begin{array}{l}\text { Ви побачили / почули, що підліток має індикатори } \\
\text { суїцидальної поведінки. Необхідно перевірити } \\
\text { Ваші побоювання. Запевніть, що для Вас важлива } \\
\text { безпека кожної людини }\end{array}$ & $\begin{array}{l}\text { Я поставлю тобі кілька запитань, які } \\
\text { стосуються безпеки. Я ставлю такі } \\
\text { питання кожній людині. Хочу } \\
\text { переконатися, що ти в безпеці, а для } \\
\text { мене дуже важливо, щоб всі люди } \\
\text { були у безпеці }\end{array}$ \\
\hline Крок 2. & $\begin{array}{l}\text { Ви ставите прямі запитання щодо думок про } \\
\text { суїцид }\end{array}$ & $\begin{array}{l}\text { Скажи, чи думаєш ти (чи є у тебе } \\
\text { думки) про те, щоб позбавити себе } \\
\text { життя? }\end{array}$ \\
\hline Крок 3. & $\begin{array}{l}\text { Запевніть, що мати думки } є \text { нормальним, коли } \\
\text { людина почуває себе погано, знаходиться у стресі } \\
\text { чи пережила складні травматичні події }\end{array}$ & $\begin{array}{l}\text { Дякую, що ти ділишся зі мною і } \\
\text { говориш відкрито. Так буває, коли } \\
\text { людина почувається погано, } \\
\text { знаходиться у стресі, то вона думає } \\
\text { про це або не хоче жити. Я маю } \\
\text { поговорити про це } 3 \text { тобою більш } \\
\text { детально }\end{array}$ \\
\hline
\end{tabular}




\section{СТВОРЕННЯ БЕЗПЕЧНОГО ШКІЛЬНОГО СЕРЕДОВИЩА: ПРОТОКОЛ БЕЗПЕКИ ПРИ СУӤЦИДАЛЬНІЙПОВЕДІНЦІПДЛІТКІВ}

\begin{tabular}{|c|c|c|}
\hline & & Продовження таблиці 1. \\
\hline Крок 4. & $\begin{array}{l}\text { 3'ясуйте, чи часто бувають такі думки, як що } \\
\text { відповідь позитивна, то яка звучить думка у голові } \\
\text { підлітка; яким чином вона оформлена;, коли } \\
\text { востаннє виникали подібні думки; як часто вони } \\
\text { виникають взагалі. Запитайте, коли саме } \\
\text { виникають думки позбавити себе життя, у який } \\
\text { час, після яких подій тощо }\end{array}$ & $\begin{array}{l}\text { Скажи, як ці думки звучать у тебе в } \\
\text { голові, чи можеш ти переказати цю } \\
\text { думку? Що ти собі промовляєш? Як } \\
\text { часто у тебе бувають такі думки, коли } \\
\text { були останнього разу? А коли, у які } \\
\text { моменти бувають думки про } \\
\text { самогубство? }\end{array}$ \\
\hline Крок 5. & $\begin{array}{l}\text { Визначте, чи } € \text { план, як закінчити життя, } \\
\text { наскільки він конкретний, чи } є \text { встановлена } \\
\text { конкретна дата здійснення плану }\end{array}$ & $\begin{array}{l}\text { Скажи, будь ласка, чи є у тебе план, } \\
\text { як позбавити себе життя? Чи } є \\
\text { конкретна дата, коли ти хочеш скоїти } \\
\text { самогубство? }\end{array}$ \\
\hline Крок 6. & $\begin{array}{l}\text { 3'ясуйте, чи є конкретний спосіб піти з життя. Чи } \\
\epsilon \text { у підлітка / дитини можливість використати } \\
\text { засоби, наприклад, пігулки, чи є ці засоби у } \\
\text { доступі? }\end{array}$ & $\begin{array}{l}\text { “Чи є у тебе доступ засобів, про які та } \\
\text { казав, наприклад, пігулок?” }\end{array}$ \\
\hline Крок 7. & Спитайте, чи були спроби самогубства раніше & $\begin{array}{l}\text { Скажи, а чи були у тебе спроби } \\
\text { вкоротити собі віку раніше? }\end{array}$ \\
\hline Крок 8. & Подякуйте за відвертість & Дякую, що ти був відвертий зі мною \\
\hline Крок 9. & $\begin{array}{l}\text { Залучити до укладення } \text { письмової } \text { угоди, } \\
\text { визначення часу дії угоди }\end{array}$ & $\begin{array}{l}\text { Мені важливо переконатися, що ти в } \\
\text { безпеці. Я знаю, що часом це може } \\
\text { бути непросто. Я хочу попрацювати } \\
\text { разом } 3 \text { тобою над тим, щоб укласти } \\
\text { план безпеки. Скажи, чи можеш ти } \\
\text { пообіцяти, що будеш триматись у } \\
\text { безпеці певний проміжок часу, } \\
\text { наприклад, три наступні дні? Дуже } \\
\text { важливо, щоб ти перебував у безпеці }\end{array}$ \\
\hline Крок 10. & $\begin{array}{l}\text { Визначте, які сигнали та ознаки з’являються перед } \\
\text { думками про самогубство, що помічає підліток } \\
\text { перед тим, як виникають ці думки }\end{array}$ & $\begin{array}{l}\text { А зараз я пропоную попрацювати } \\
\text { разом над питанням твоєї безпеки. } \\
\text { Скажи, будь ласка, які сигнали або } \\
\text { ознаки з'являються перед тим, як ти } \\
\text { починаєш думати про самогубство? } \\
\text { Що ти зазвичай помічаєш перед } \\
\text { такими думки? }\end{array}$ \\
\hline Крок 11. & $\begin{array}{l}\text { Запитайте, як дитина почувається в такі моменти, } \\
\text { що вона зазвичай робить }\end{array}$ & $\begin{array}{l}\text { Як ти почуваєшся у ці моменти? Що } \\
\text { ти робиш зазвичай? }\end{array}$ \\
\hline Крок 12. & $\begin{array}{l}\text { 3'ясуйте, а ще у яких ситуаціях підліток } \\
\text { найчастіше думає про самогубство }\end{array}$ & $\begin{array}{l}\text { Скажи, а у яких ще ситуаціях ти } \\
\text { найчастіше думаєш про самогубство? }\end{array}$ \\
\hline Крок 13. & $\begin{array}{l}\text { Розпитайте, що підліток зазвичай робить, щоб } \\
\text { подолати думки про самогубство. Підтримайте } \\
\text { самостійні спроби дитини відкинути ці думки. } \\
\text { Залучайте до додаткових пошуків і спроб } \\
\text { впоратися з думками }\end{array}$ & $\begin{array}{l}\text { Що ти робиш зазвичай, щоб подолати } \\
\text { ці думки про самогубство? } \\
\text { Як це добре! Ти знайшов хороший } \\
\text { спосіб впоратися зі своїм станом! } \\
\text { Може, тобі ще щось допомагає? }\end{array}$ \\
\hline Крок 14. & $\begin{array}{l}\text { Допоможіть утриматися підлітку від виконання } \\
\text { плану дій щодо скоєння самогубства. Домовтеся про } \\
\text { певний час, коли підліток зможе утриматися від дій, } \\
\text { пов'язаних } 3 \text { планом. Чим вищий рівень небезпеки } \\
\text { вчинення суӥциду, тим коротший термін дії } \\
\text { плану. Він може складати 1, 2, } 3 \text { дні. Після } \\
\text { завершення цього терміну необхідно зустрітися } 3 \\
\text { дитиною повторно і перевірити рівень безпеки, } \\
\text { можливо підписати ще один план безпеки. } \\
\text { Додаткові дії після повторного написання плану } \\
\text { безпеки наведено нижче таблиці } 2\end{array}$ & $\begin{array}{l}\text { Скажи, як щодо твого плану - } \\
\text { наковтатися пігулок? Чи можемо } \\
\text { обміркувати, як убезпечити тебе від } \\
\text { виконання цих дій. } \\
\text { Чи можемо домовитися, що певний } \\
\text { час ти не вживатимеш жодних } \\
\text { пігулок, поки не знизиться ризик? }\end{array}$ \\
\hline
\end{tabular}




\section{СТВОРЕННЯ БЕЗПЕЧНОГО ШКІЛЬНОГО СЕРЕДОВИЩА: ПРОТОКОЛ БЕЗПЕКИПРИ СУӤЦИДАЛЬНІЙПОВЕДІНЦІПДЛТТКІВ}

\begin{tabular}{|c|c|c|}
\hline \multicolumn{3}{|r|}{ Продовження таблиці 1.} \\
\hline Крок 15. & $\begin{array}{l}\text { Запропонуйте позбавитися засобів можливого } \\
\text { скоєння суїциду, наприклад, віддати їх батькам, } \\
\text { рідним, якщо підліток має ці засоби із собою }\end{array}$ & $\begin{array}{l}\text { Скажи, будь ласка, чи ти можеш } \\
\text { пообіцяти віддати пігулки батькам чи } \\
\text { друзям сьогодні? Кому і коли ти } \\
\text { віддасиш свої пігулки? }\end{array}$ \\
\hline Крок 16. & $\begin{array}{l}\text { Запропонуйте записати все, що ви обговорили у } \\
\text { план безпеки }\end{array}$ & $\begin{array}{l}\text { Я пропоную скласти разом } \\
\text { письмовий план про твою безпеку, в } \\
\text { якому перерахуємо всі моменти, які } \\
\text { щойно обговорили }\end{array}$ \\
\hline Крок 17. & $\begin{array}{l}\text { Запропонуйте допомогу, якщо дитина відчує, що } \\
\text { не зможе самостійно впоратися з думками i } \\
\text { власним емоційним станом. Вкажіть телефон і } \\
\text { визначте час, коли дитина може сконтактувати } 3 \\
\text { Вами. } \\
\text { Зробіть це тільки у тому разі, коли Ви справді } \\
\text { відчуваєте, що можете це зробити. Якщо це для } \\
\text { Вас складно - не робіть цього, краще } \\
\text { перенаправте підлітка до іншого фахівця }\end{array}$ & $\begin{array}{l}\text { Якщо ти відчуєш, що сам будеш не } \\
\text { змозі впоратися } 3 \text { думками про } \\
\text { самогубство, } \\
\text { зателефонувати мені, ось телефон } \\
\text { час, коли ти можеш це зробити }\end{array}$ \\
\hline Крок 18. & $\begin{array}{l}\text { Запропонуйте номери телефонів довіри та гарячих } \\
\text { ліній для підтримки підлітка }\end{array}$ & $\begin{array}{l}\text { Я пропоную тобі список телефонів } \\
\text { довіри та гарячих ліній, куди ти } \\
\text { можеш безкоштовно зателефонувати } \\
\text { у випадку, коли тобі буде складно і } \\
\text { ти відчуєш потребу поговорити }\end{array}$ \\
\hline Крок 19. & $\begin{array}{l}\text { У випадку, якщо підліток відчує, що не в змозі } \\
\text { самостійно впоратися зі своїм станом, } \\
\text { запропонуйте йому подумати, кого б він запросив } \\
\text { для підтримки побути поряд }\end{array}$ & $\begin{array}{l}\text { Якщо ти відчуєш, що самостійно не } \\
\text { можеш впоратися зі своїм емоційним } \\
\text { станом, кого ти запросив би для } \\
\text { підтримки? }\end{array}$ \\
\hline Крок 20. & $\begin{array}{l}\text { Напишіть строк дії плану безпеки. Запропонуйте } \\
\text { підписати його підлітку. Подякуйте за відвертість }\end{array}$ & $\begin{array}{l}\text { Дякую тобі за відвертість. Наш план } \\
\text { безпеки діє від сьогодні на три дні. } \\
\text { Через три дні ми зустрінемося, щоб } \\
\text { 3’ясувати, як ти себе почуваєш. Я } \\
\text { дуже дякую тобі за розмову }\end{array}$ \\
\hline
\end{tabular}

вузькопрофільного фахівця, наприклад, до центру психосоціальної реабілітації, кризового центру, психотерапевта. Рекомендуйте батькам або особам, що їх замінюють, отримати консультацію у лікаря психіатра. Перенаправивши, обов'язково 3'ясуйте, чи отримала дитина додаткову консультацію спеціаліста. Розділіть відповідальність за життя дитини з їі батьками, іншими фахівцями 3 питань психічного здоров'я.

Педагогічним працівникам треба враховувати ситуацію, якщо підліток заперечує існування проблеми, або не хоче розмовляти. Це означає, що він/вона може не бути готовою розмовляти безпосередньо зараз. У такому випадку треба: сказати, що Ви поряд, що з Вами можна поговорити, якщо йому/їй буде потрібно; продовжити шукати можливості спілкування 3 дитиною, бути в контакті, виходити 3 нею на зв’язок; запропонувати ще когось, 3 ким би могла поговорити дитина.

Висновки і перспективи подальших розвідок. Педагогічні працівники можуть виявляти підлітків, які мають суїцидальну поведінку, бо постійно спілкуються 3 ними в закладах освіти. Для визначення рівня ризику суїцидальної поведінки серед підлітків педагогічні працівники мають знати ситуативні, поведінкові та комунікативні індикатори суїцидального ризику. Використання покрокового протоколу супроводу підлітка, який має середній, високий та надвисокий рівень ризику скоєння суїциду допоможе зберегти життя та здоров'я дитини, сприятиме створенню безпечного шкільного середовища.

Центр психічного здоров'я та психосоціальної підтримки НаУКМА у співпраці з МОН, іншими національними і міжнародними партнерами 


\section{СТВОРЕННЯ БЕЗПЕЧНОГО ШКІЛЬНОГО СЕРЕДОВИЩА: ПРОТОКОЛ БЕЗПЕКИ ПРИ СУӤЦИДАЛЬНІЙПОВЕДІНЦІПДЛІТКІВ}

розробив складну модель психосоціальної підтримки в школах під назвою "Безпечний простір”, що побудована на основі низки доказових втручань на різних рівнях освітнього процесу. Важливо збільшити кількість досліджень в освітній сфері, спрямованих на збір нових доказів і на вивчення процесу впровадження.

\section{ЛIТЕРАТУРА}

1. World Health Organization. Suicide. URL: $\underline{\text { https:// }}$ www.who.int/news-room/fact-sheets/detail/suicide (дата звернення 17.07.2021)

2. Укрінформ. В Україні торік вчинили самогубство 123 підлітки. URL: https://www.ukrinform.ua/rubricsociety/3213177-v-ukraini-torik-vcinili-samogubstvo-123pidlitki-mvs.html (дата звернення 17.07.2021)

3. Закон України "Про внесення зміни до статті 120 Кримінального кодексу України щодо встановлення кримінальної відповідальності за сприяння вчиненню самогубства". URL: https://zakon.rada.gov.ua/laws/ show/2292-19\#Tехt (дата звернення 17.07.2021)

4. Лист МОН “Щодо профілактики суїцидальних тенденцій серед учнів” від 28.03.14 №1/9-179. URL: https:/ /mon.gov.ua/ua/osvita/pozashkilna-osvita/ psihologichna-sluzhba (дата звернення 17.07.2021)

5.Лист МОН "Методичні рекомендації щодо запобігання та протидії насильству” від 18.05.2018 №1/ 11-5480. URL: https://imzo.gov.ua/2018/05/21/lyst-monvid-18-05-2018-1-11-5480-metodychni-rekomendatsijischodo-zapobihannya-ta-protydiji-nasylstvu/ (дата звернення 17.07.2021)

6. Богданов С. О., Гірник А. М., Залеська О. В. та ін. Підготовка вчителів до розвитку життєстійкості / стресостійкості у дітей в освітніх навчальних закладах: навч.-метод. посіб. Київ: Пульсари, НаУКМА, 2017. 208 с.

7. Богданов С. О., Гніда Т. Б., Залеська О. В. та ін. Корекційно-розвиткова програма формування стійкості до стресу в дітей дошкільного віку та школярів "Безпечний простір“: навч.-метод. посіб. Київ: ГЛІФ Медіа, НаУКМА. 208 с.

8. Федоренко Р. П. Психологія суїциду: навч. посіб. Луцьк: ВНУ ім. Лесі Українки, 2011. 260 с.

9. Гук О., Гриник І. Профілактика суїцидальної поведінки підлітків як актуальна соціально-педагогічна проблема. Молодь і ринок. Щомісячний науковопедагогічний журнал. Дрогобич, 2021. №2 (188). С. 81 84.

10. World Health Organization. Public Health Action for the Prevention of Suicide: a Framework. URL: $\underline{\text { https:// }}$ apps.who.int/iris/bitstream/handle/10665/75166/ 9789241503570 eng.pdf(дата звернення 17.07.2021)

\section{REFENCES}

1. World Health Organization (2021). Suicide. Available at: https://www.who.int/news-room/fact-sheets/detail/ suicide (Accessed 17 July 2021) [in English].

2. Ukrinform (2021). V Ukraini torik vchynyly samohubstvo 123 pidlitky [In Ukraine 123 teenagers committed suicide last year]. Available at: https:// www.ukrinform.ua/rubric-society/3213177-v-ukraini-torikvcinili-samogubstvo-123-pidlitki-mvs.html (Accessed 17 July 2021) [in Ukrainian].

3. Zakon Ukrainy "Pro vnesennia zminy do statti 120 Kryminalnoho kodeksu Ukrainy shchodo vstanovlennia kryminalnoi vidpovidalnosti za spryiannia vchynenniu samohubstva" (2018). [Law of Ukraine "On Amendments to Article 120 of the Criminal Code of Ukraine Concerning the Establishment of Criminal Liability for Promoting Suicide"]. Available at: https://zakon.rada.gov.ua/laws/ show/2292-19\#Text (Accessed 17 July 2021) [in Ukrainian].

4. Lyst MON (2014). "Shchodo profilaktyky suitsydalnykh tendentsii sered uchniv” vid 28.03.14 №1/ 9-179 [Letter of the Ministry of Education and Science "On the prevention of suicidal tendencies among students"]. Available at: https://mon.gov.ua/ua/osvita/ pozashkilna-osvita/psihologichna-sluzhba (Accessed 17 July 2021) [in Ukrainian].

5. Lyst MON (2018). "Metodychni rekomendatsii shchodo zapobihannia ta protydii nasylstvu" vid 18.05.2018 №1/11-5480 [Letter of the Ministry of Education and Science "Guidelines for preventing and combating violence"]. Available at: https://imzo.gov.ua/2018/05/21/ lyst-mon-vid-18-05-2018-1-11-5480-metodychnirekomendatsiji-schodo-zapobihannya-ta-protydijinasylstvu/ (Accessed 17 July 2021) [in Ukrainian].

6. Bohdanov, S.O., Hirnyk, A.M., Zaleska, O.V., Ivaniuk, I.V., Solovyova, V.V., Chernobrovkina, V.A. \& Chernobrovkin, V.M. (2017). Pidhotovka vchyteliv do rozvytku zhyttiestiikosti / stresostiikosti u ditei v osvitnikh navchalnykh zakladakh [Preparation of teachers for the development of vitality / stress resistance of children in schools]. Manual. Kyiv, Pulsary, NaUKMA. 208 p. [in Ukrainian].

7. Bohdanov, S.O., Hnida, T,B., Zaleska, O.V., Lunchenko N.V., Panok, V.H. \& Solovyova, V.V. (2017). Korektsiino-rozvytkova prohrama formuvannia stiikosti do stresu v ditei doshkilnoho viku ta shkoliariv "Bezpechnyi prostir" [Correctional and developmental program for the formation of resistance to stress in preschool children and schoolchildren "Safe Space"]. Manual. Kyiv, Glifmedia, NaUKMA. 208 p. [in Ukrainian].

8. Fedorenko, R.P. (2011). Psykholohiia suitsydu [Psychology of suicide]. Manual. Lutsk: University named after Lesya Ukrainka. 260 p. [in Ukrainian].

9. Huk, O. \& Hrynyk, I. Profilaktyka suitsydalnoi povedinky pidlitkiv yak aktualna sotsialno-pedahohichna problema [Prevention of suicidal behavior of adolescents as an urgent socio-pedagogical problem]. "Youth and market". Monthly scientific-pedagogical journal. Drogobych,Vol.2 (188). pp. 81 - 84. [in Ukrainian].

10. World Health Organization (2012). Public Health Action for the Prevention of Suicide: a framework. Available at: https://apps.who.int/iris/bitstream/handle/10665/ 75166/9789241503570 eng.pdf(Accessed 17 July 2021) [in English].

Стаття надійшла до редакції 21.07.2021 